\title{
Deneysel Ülseratif Kolit Üzerine Yüksek Karbonhidratlı, Yüksek Yağlı ve Aralıklı Beslemenin Etkisi
}

\author{
Ahmet UYAR ${ }^{1 *}$, Hüseyin EMLiK², Turan YAMAN ${ }^{3}$ \\ ${ }^{1^{*}}$ Mustafa Kemal Üniversitesi, Veteriner Fakültesi, Patoloji Anabilim Dalı, Hatay, Türkiye. \\ ${ }^{2}$ Yüzüncü Yıl Üniversitesi, Veteriner Fakültesi, Fizyoloji Anabilim Dalı, Van, Türkiye. \\ ${ }^{3}$ Yüzüncü Yıl Üniversitesi, Veteriner Fakültesi, Patoloji Anabilim Dalı, Van, Türkiye.
}

Geliş Tarihi: 03.11.2017

Kabul Tarihi: 28.12.2017

\begin{abstract}
Özet: Bu çalışmada, dünyada görülme sıklığı artan inflamatuvar bağırsak hastalıklarının (ïB) bir tanesi olan Ülseratif kolit (ÜK) hastalığının Wistar albino türü ratlarda deneysel oluşumu üzerine beslenme şekli ve sıklığııın karşılaştırmalı olarak araştıııması amaçlanmıştır. Bu amaçla; Kontrol (n=7), Kolit ( $n=7)$, Kolit-Yüksek Karbonhidratı Diyet (K-YKD) (n=7), Kolit-Yüksek Karbonhidratlı Aralıklı Diyet (K-YKAD) ( $n=7)$, Kolit-Yüksek Yağı Diyet (K-YYD) ( $n=7)$, Kolit-Yüksek Yağlı Aralıkı Diyet (K-YYAD) ( $n=7)$ olacak şekilde çalışma grupları oluşturuldu. Gruplardan aralıkı besleme gruplarına haftada sadece 2 gün (ardarda olmayan) diyet verilmesine 24 saat ara verildi. 7 haftalık beslemeden sonra deneysel kolit modeli; kolit ve tedavi gruplarındaki (Kolit, K-YKD, K-YKAD, K-YYD, K-YYAD) ratlara anestezi altında $30^{\circ}$ trendelenburg pozisyonunda $8 \mathrm{~mm}$ lik kateterin rektal yoldan $8 \mathrm{~cm}$ ileriye asetik asidin $(\mathrm{pH} 2.4, \% 4)$ intrarektal (i.r.) olarak uygulanması ile oluşturuldu. 72 saat sonra ratlar sakrifiye edilerek histopatolojik örnekler \%10 tamponlu formaldehite alındı. Histopatolojik incelemelere göre asetik asitin ciddi kolit hasarlarına neden olduğu buna karşın aralıklı olarak verilen diyet gruplarında bu hasarların oldukça minimal düzeyde kaldığı görülmüştür. Sonuç olarak kolit modelinde aralıklı diyet uygulamasının olumlu etkileri olduğu kanısına varıldı.
\end{abstract}

Anahtar Kelimeler: Yüksek Karbonhidratlı, Yağlı ve Aralıklı Diyet, Kolit, Rat.

\section{Effect of High Carbohydrate, Fat and Intermittent Fasting Diet on Experimental Ulcerative Colitis}

\begin{abstract}
In this study, it was aimed to comparatively investigate the effect of diet type and feeding frequency on occurence of experimental ulcerative colitis (UC), in Wistar albino rats. For this purpose, 7 rats were randomly selected and 6 groups were formed as Control ( $n=7)$, Colitis ( $n=7)$, Colitis-High Carbohydrate Diet (C-HCD) ( $n=7)$, Colitis - High Carbohydrate Diet with Intermittent Feeding (CHCIFD) ( $n=7)$, Colitis -High Fat Diet (C-HFD) ( $n=7)$, Colitis-High Fat Diet with Intermittent Feeding (C-HFIFD) ( $n=7)$. In intermittent feeding groups the feeding was interrupted twice in a week for 24 hours. After 7 weeks of feeding, experimental colitis model was induced in colitis and treatment groups rats by intrarectal administration of acetic acid (pH 2.4, $4 \%$ ). After the 72 hours rats were sacrificed and colon samples were taken into $10 \%$ formalin solution. Histopathological studies have shown that acetic acid caused severe colitis damage, whereas the damage remained at minimal levels in groups with intermittent feeding. As a result, it was concluded that intermittent feeding administration in the colitis model had positive effects.

Keywords: High Carbohydrate, Fat and Intermittent Fasting Diet, Colitis, Rat.
\end{abstract}

\section{Giriş}

Inflamatuvar Bağırsak Hastalığı (iBH) gastrointestinal kanalın kronik, idyopatik inflamasyonu ile karakterize hastalı̆̆ olup Ülseratif Kolit (ÜK) ve Crohn hastalı̆̆ $(\mathrm{CH})$ olmak üzere iki klinik formdan oluştuğu belirtilmektedir. ÜK genellikle kolon ve rektumu etkilemesine karşın, $\mathrm{CH}$ gastro-intestinal kanalın herhangi bir kısmında görülebilmektedir (Daneshmand ve ark., 2011; Nagib ve ark., 2013). Hastalı̆ın her iki formunun ortak özelliği başta gastrointestinal kanal olmak üzere tüm vücut sistemlerini etkileyebilmesidir (Griffiths ve Buller, 2000).

Inflamatuvar barsak hastalıklarının etiyolojisinde çeşitli enfeksiyöz etkenler, allerjenler, beslenme alışkanlıkları, psikosomatik faktörler ve otoantijenlere karşı gelişen immun yanıt (Ordás ve ark., 2012; Podolsky, 2002), patogenezinde ise mukoza koruyucu faktörlerin dengesinde bozulma, aşırı bakteri çoğalması, sitokin ve mediatör sentezindeki değişiklikler sorumlu tutulmaktadır (Dieleman, 1994).

Sağlıklı bir beslenme düzeninde günlük olarak gereksinim duyulan enerjinin \%50-55'i karbonhidratlardan, \% 25-30'si yağlardan (\%15 tekli doymamış, \%15 çoklu doymamış) geri kalan \% 15'i de proteinlerden karşılanmalıdır (Hopfer, 1997). Yetersiz beslenmeye ve organizmanın ihtiyacı olan besinlerin eksikliğine sebebiyet vermeden diyetin azaltılması aralıklı besleme veya kalori kısıtlaması şeklinde çeşitli inflamatuvar hastalıklarda uygulanmaktadır (Akman ve ark., 2004; Longo ve Panda, 2016). Bu yöntemlerde glikolizis azalmakta, glikoneogenesis ve transaminasyon mekanizmaları hızlanmaktadır. Dolayısı ile glikolitik mekanizmalardan öte diğer besin maddelerinin oksidasyonu hızlanmaktadır (Hagopian ve ark., 2005). Diyetin inflamatuvar barsak hastalığı etiyolojisinde rolü 
tam olarak ortaya konmasa da çok az yapılan çalışmada artan karbonhidrat, şeker, nişasta alınımı ile kolit arasındaki ilişki araştııılmıştır (Chan ve ark., 2014).

Yapılan bu çalışmada yüksek karbonhidratlı ve yüksek yağlı diyetlerle aralıklı beslemenin asetik asit ile deneysel olarak kolit oluşumu üzerine etkisi amaçlanmıştır.

\section{Materyal ve Metot}

Deney hayvanları, deney düzeni ve diyet hazırlanması: Yapılan bu çalışmada Yüzüncü Yıl Üniversitesi Tıp Fakültesi Deney Hayvanları Birimi'nden temin edilen 200-250 g ağırlıklı 2-2,5 aylık yaşta olan 42 adet erkek Wistar albino türü rat kullanıldı. Ratlar \% 50-60 nem oranı, $22 \pm 1{ }^{\circ} \mathrm{C}$ oda ISISI, ışık düzeni 12 saat gündüz/12 saat gece olan ortamda tutuldu. Deneme, YUHADYEK (Yüzüncü Yıl Üniversitesi Hayvan Deneyleri Yerel Etik Kurulu) tarafından onay alınarak (30.07.2015 tarih ve 09 sayılı kararı) gerçekleştirildi.

Her grupta 7'şer adet olacak şekilde ratlar Kontrol, Kolit, Kolit-Yüksek Karbonhidratlı Diyet (K-YKD), KolitYüksek Karbonhidratlı Aralıklı Diyet (K-YKAD), KolitYüksek Yağlı Diyet (K-YYD), Kolit-Yüksek Yağlı Aralıklı Diyet (K-YYAD) olarak 6 gruba ayrıldı. Deneysel kolit oluşturmak amacıyla ketalar $(50 \mathrm{mg} / \mathrm{kg}$ ) ve rompun (10 $\mathrm{mg} / \mathrm{kg}$ ) ile anesteziye alınarak $30^{\circ}$ trendelenburg pozisyonuna getirilen ratlara $8 \mathrm{~mm}$ 'lik kateter, rektal yoldan $8 \mathrm{~cm}$ ileriye uzanacak şekilde yerleştirildi. Kolit, KYKD, K-YKAD, K-YYD, K-YYAD grubu ratlara $1 \mathrm{ml}, \mathrm{pH} 2.4$, $\% 4^{\prime}$ lük asetik asit intrarektal (ir) olarak uygulandı. Kontrol grubundaki ratlara ise eş zamanlı olarak ir yoldan $1 \mathrm{ml}$ serum fizyolojik (nötr $\mathrm{pH}$ 'da \% 0.9'luk $\mathrm{NaCl}$ ) verildi. Uygulanan maddelerin geri kaçmasını engellemek için denekler 30 sn süreyle kuyruktan kaldırılarak baş aşağı şekilde tutuldu ve sonrasında yine trendelenburg pozisyonunda anesteziden çıkana kadar yaklaşık $30 \mathrm{dk}$ bekletildi. Tüm gruplardaki ratlar ir asetik asit veya serum fizyolojik uygulamasından 72 saat sonra sakrifiye edildi. Tüm grupların nekropsileri yapılarak transvers kolonun ortasından rektumun distaline kadar uzanan yaklaşık $10 \mathrm{~cm}$ 'lik kolon segmenti çıkarıldı ve fekal içeriği serum fizyolojik ile temizlendi. Kolon hasarının derecesi Morris ve ark. (1989)'nın Tablo 1'de belirtilen sınıflandırmasına göre lup kullanılarak makroskobik skorlama yapıldı. Kolon dokularında makroskobik hasarın en fazla olduğu kısımlar histopatolojik inceleme amaciyla \% 10'luk tamponlu formaldehit içine alınarak 72 saat süreyle tespit edilmeleri sağlandı. Rutin takip işlemi kapsamında; doku örnekleri alkol serilerinden geçirilerek dehidrasyonları; ksilol serilerinden geçirilerek şeffaflandırımaları sağlandı ve daha sonra parafinde bloklandı. Bu bloklardan mikrotomda (Leica RM 2135) 4 mikron kalınlığında alınan seri kesitler HematoksilenEozin (H.E.) ile boyandıktan sonra ışık mikroskobunda (Nikon 80i-DS-Ri2) Appleyard ve Wallace (1995) tarafından Tablo 2'de belirlenen mikroskobik kriterlere göre incelenerek fotoğrafları çekildi. Günlük yüksek yağlı diyet hazırlamak amacıyla 100 gram standart pellet yeme 25 g yağ yağ eritilerek eklendi (Zhou ve ark., 1998). Yüksek karbonhidratlı diyet ile beslenecek ratlara standart diyetle beraber sularına sükroz (300 g/l) takviyesi yapıldı (Malafaia ve ark., 2013). Deneysel süreç 7 hafta sürdürüldü. Bütün gruplar bu süreç boyunca yiyebildikleri kadar uygun diyet ve su ile beslendiler. Gruplardan aralıklı besleme grubuna haftada sadece 2 gün (Pazartesi ve Perşembe günleri) diyet verilmesine 24 saat ara verildi.

Tablo 1. Kolon dokusu makroskobik sınıflandırma kriterleri (Morris ve ark., 1989).

\begin{tabular}{|c|c|}
\hline Skor & Makroskobik inceleme \\
\hline $\mathbf{0}$ & Normal görünümlü mukoza \\
\hline 1 & Lokalize hiperemi, ülser yok \\
\hline 2 & Belirsiz inflamasyonlu linear ülser \\
\hline 3 & Bir bölgede inflamasyonlu linear ülser \\
\hline 4 & $\begin{array}{l}\text { İki yada daha fazla inflamasyon ve/veya ülserasyon } \\
\text { bölgesi }\end{array}$ \\
\hline 5 & $\begin{array}{l}\text { İki veya daha fazla major inflamasyon ve ülserasyon } \\
\text { bölgesi yada kolonda } 1 \mathrm{~cm} \text { 'den daha büyük bir tane } \\
\text { inflamasyon ve ülserasyon bölgesi }\end{array}$ \\
\hline
\end{tabular}

Tablo 2. Kolon dokusu mikroskobik değerlendirme kriterleri (Appleyard ve Wallace, 1995).

\begin{tabular}{lcccc}
\hline Skor & \multicolumn{4}{c}{ Mikroskobik inceleme } \\
\cline { 2 - 5 } & $\begin{array}{c}\text { Mukozal } \\
\text { yapı } \\
\text { kaybı }\end{array}$ & $\begin{array}{c}\text { Hücresel } \\
\text { infiltrasyon }\end{array}$ & $\begin{array}{c}\text { Kript } \\
\text { apsesi }\end{array}$ & $\begin{array}{c}\text { Goblet } \\
\text { hücre } \\
\text { azalması }\end{array}$ \\
\hline $\mathbf{0}$ & Yok & Yok & Yok & Yok \\
$\mathbf{1}$ & $<\% 5$ & Az & Var & Var \\
$\mathbf{2}$ & $\% 5-\% 10$ & Orta & - & - \\
$\mathbf{3}$ & $>\% 10$ & Belirgin & - & - \\
\hline
\end{tabular}

İstatistiksel Analiz: İstatistiksel analiz, SPSS yazılımı (Ver. 22; IBM-SPSS) kullanılarak yapıldı. Ölçüm verileri ortalama \pm standart hata şeklinde sunuldu. Gruplar arasındaki verilerin farklılaşmasının önemi tek yönlü varyans analizi (Oneway ANOVA) ile belirlendi.

\section{Bulgular}

Makroskobik bulgular: Makroskobik sınıflandırma kriterlerine göre (Morris ve ark., 1989) skor değerlendirmesi Şekil 1'de sunulmuştur. Kontrol grubu ratların kolonlarında herhangi bir makroskobik bulguya rastlanılmamıştır. Kolit grubunda hasar skoru 4 olan 3 rat ve hasar derecesi 5 olan 4 rat tespit edilmiştir. K-YKD 
grubunda hasar skoru 1, 3 ve 5 olan birer rat bulunurken 2 ve 4 olan ikişer rat, K-YKAD grubunda ise hasar skoru 1 olan üç rat, 2 olan iki rat ve 3, 4 olan birer rat tespit edilmiştir. K-YYD grubunda hasar skoru 1 olan üç rat, 2, 3 olan birer rat ve 4 olan bir rat, K-YYAD grubunda ise hasar skoru 1 olan beş rat ve 2 olan iki rat tespit edilmiştir. Bu sonuçlara göre kolitli tüm beslenme gruplarının kolon dokularında makroskobik olarak farklı derecelerde hasar olduğu görülmüştür. Gruplara ait makroskobik olarak kolon görünümleri Şekil $2 \mathrm{~A}-\mathrm{H}^{\prime} \mathrm{de}$ sunulmuştur.
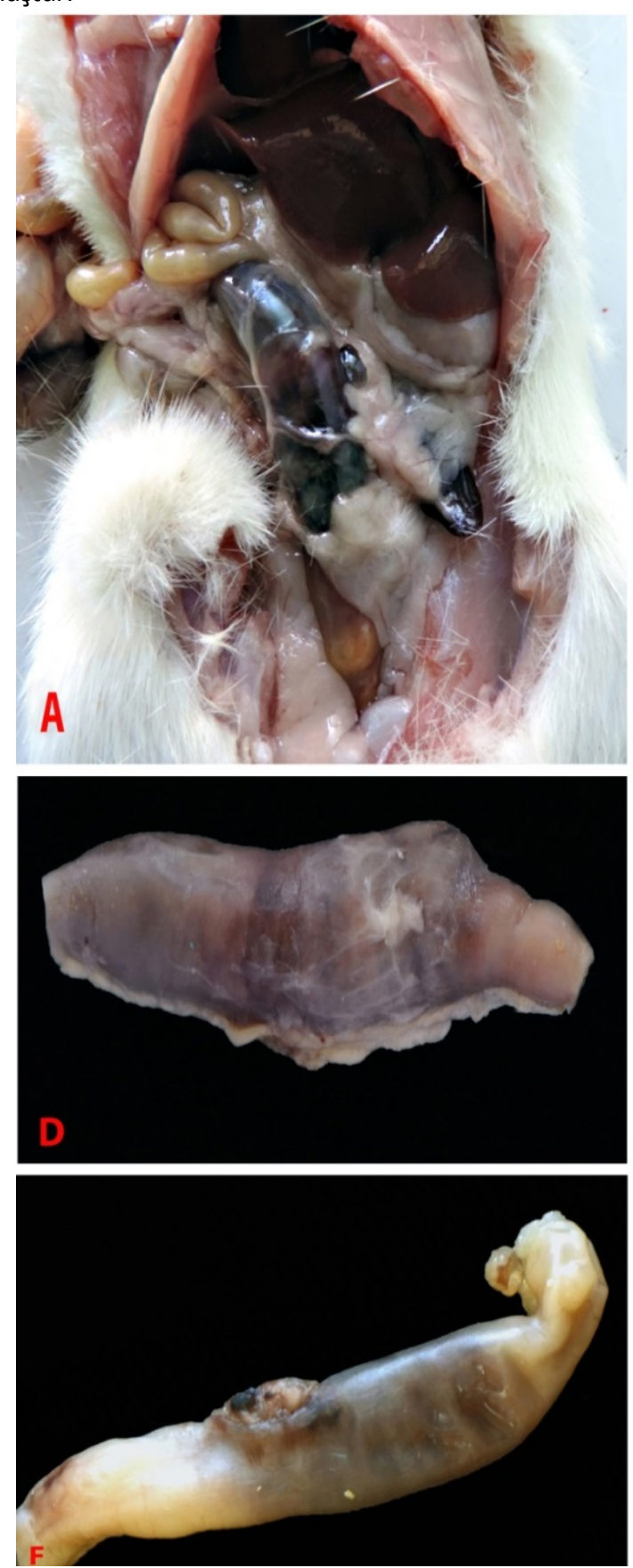

Şekil 2. A-H. Laparotomi sırası ve sonrası gruplara göre kolon dokusunun makroskobik görünümü. A: Kolit grubu ratın laparatomi sırasında görünümü. B: Kontrol grubu C: Kolit grubu D: K-YYD grubu E: K-YYDA grubu F: K-YKD grubu H: KYKDA grubu.

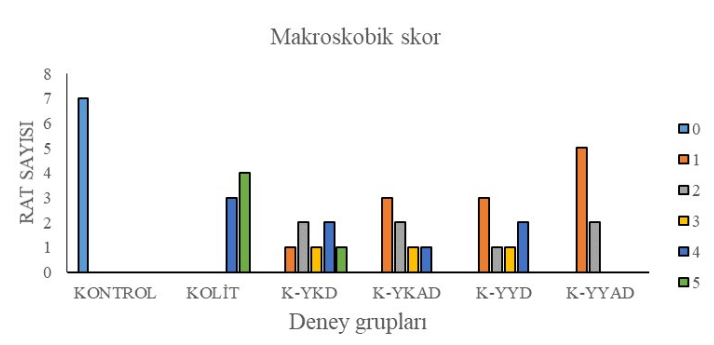

Şekil 1. Tüm gruplarda makroskobik hasarın dağııımı
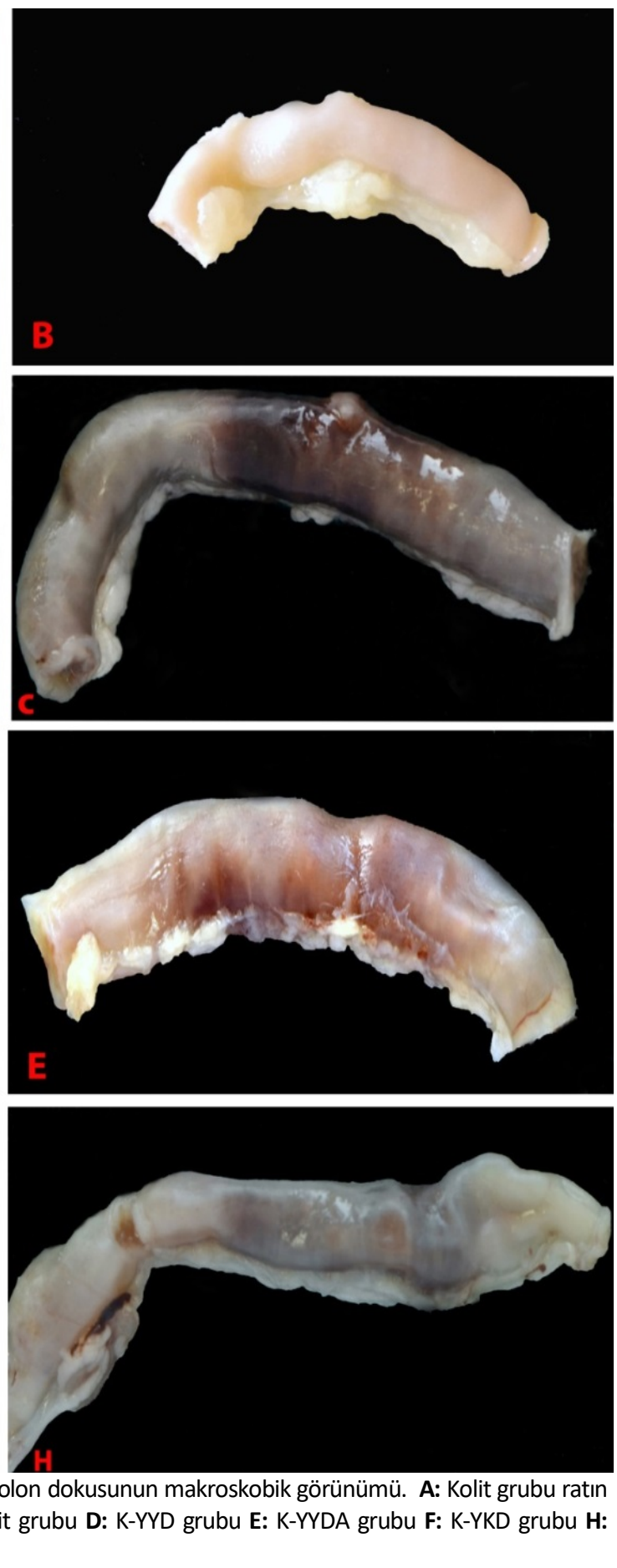
Mikroskobik bulgular: Mikroskobik sınıflandırma kriterlerine göre (Appleyard ve Wallace, 1995) skor değerlendirmeleri Şekil 3, 4, 5 ve 6 'da sunulmuştur. Kontrol grubu ratların kolonlarının mikroskobik incelenmesinde normal histolojik yapıya sahip kriptler görüldü. Kolit grubunda ise kriptlerde çok şiddetli erozyon, mukozal ve submukozal yoğun inflamatuvar hücre infiltrasyonu ve çok şiddetli yaygın hemoraji, submukozal ödem, vaskülitis ve mukozal epiteldeki lezyonlar sonucunda bezlerden koparak bağırsak lümenine dökülen piknotik nukleuslu nekrotik hücrelere rastlanıldı. YKD ve YYD grubunda kolit grubundaki bulgulara yakın derecede kriptlerde erozyon, hafif derecede mukozal ve submukozal inflamatuvar hücre infiltrasyonu, hemoraji ve yaygın submukozal ödem görüldü. Aralıklı diyetin uygulandığı K-YKDA ve K-YYDA gruplarında kriptler normal histolojik yapısını korumakla birlikte Kolit, YKD ve YYD gruplarına oranla daha çok daha hafif derecede kriptlerde erozyon, mukozal ve submukozal inflamatuar hücre infiltrasyonu, fokal hemoraji fokal submukozal ödeme rastlanılmıştır. Kolon hasarının mikroskobik görüntüleri Şekil 7 A-F'de sunulmuştur.

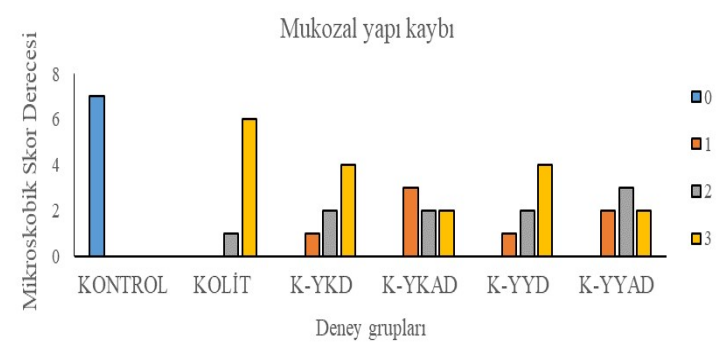

Şekil 3. Tüm gruplarda mukozal yapı kaybı skorları.

\section{Tartışma ve Sonuç}

Gelişmiş olan ülkeler ile bu ülkelerdeki kentsel yaşam tarzı, gelişmekte olan ülkelerdeki kırsal yaşam tarzına göre daha yüksek bir İH insidansına sahip olduğu, bu etkinin popülasyonların yaşam biçimindeki değişikliklerle ilişkilendirildiği bildirilmiştir (ChapmanKiddell ve ark., 2010; Ordás ve ark., 2012). Deneysel hayvan modelleri ile intestinal inflamasyon oluşturularak IBH'nin patogenezi ve yeni tedavi yöntemlerinin etkisi araştırımıştır (Ewaschuk ve Dieleman, 2006). IBH'si olan hastalar, hastalıklarını kontrol etmek için farmakolojik olmayan yaklaşımlara giderek daha fazla yönelmektedir. Son 20 yılda ucuz, lezzetli ve yüksek yağ içeren birçok gıda maddesinin ortaya çıkmasıyla diyetteki yağ miktarı hızla artmıştır (Schrauwen ve Westerterp, 2000). Yüksek yağ içeren diyet (YYD) ile beslenme, insan ve hayvanlarda başta obezite olmak üzere birçok metabolik hastalıkları indükleyebilmektedir. İnsanlarda ve diğer canlı

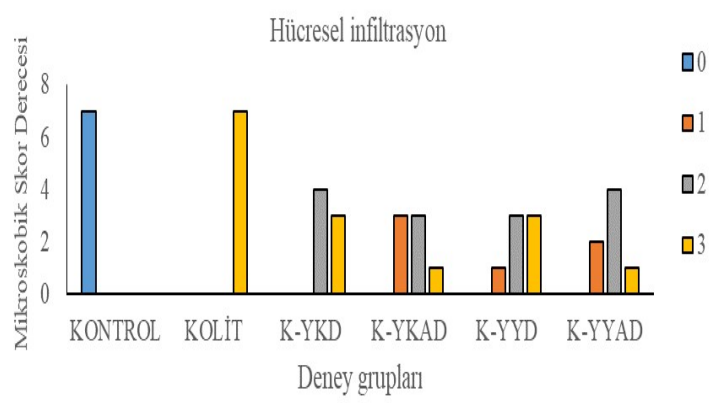

Şekil 4. Tüm gruplarda hücresel infiltrasyon skorları.

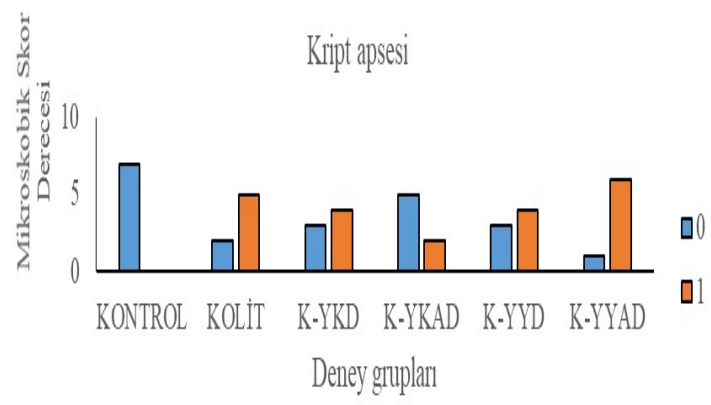

Şekil 5. Tüm gruplarda kript apsesi skorları.

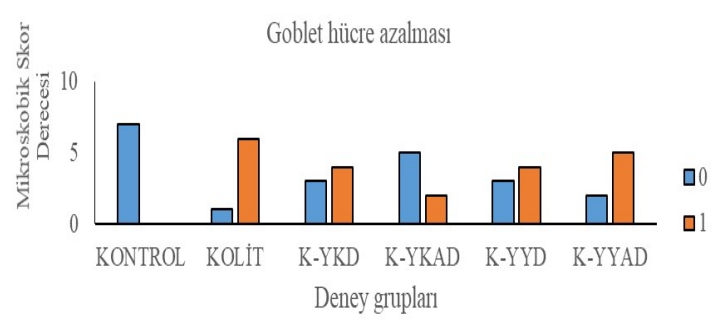

Şekil 6. Tüm gruplarda goblet hücre azalması skorları.

türlerinde vücut homeostazını bozmadan alınan kalori miktarı kısıtlanabilir. Kalori kısıtlamasının obezite, kardiyovasküler hastalıklar, Diabetes mellitus (DM), kanser, otoimmun hastalıklar gibi birçok hastalıkların ortaya çıkmasını engellediği bildirilmiştir (Kumar ve ark., 2007). Bu çalışmada yüksek karbonhidratlı ve yüksek yağlı ve aralıklı beslenmenin deneysel olarak kolit oluşumu üzerine etkisinin histopatolojik sonuçları irdelendi. Araştırmacılar kolit oluşturmak amacıyla yaptıkları deneysel çalışmalarda irritanları lüminal olarak (asetik asit, oksazolon, trinitrobenzen sulfonik asit) veya içme suyuna katarak (dekstran sodyum sülfat) kullanmaktadırlar. Yapılan bu çalışmada literatürde (Hagar ve ark., 2007) belirtilen yönteme göre ratlara yumuşak pediatrik sonda, rektal yolla $8 \mathrm{~cm}$ ileriye ulaşacak şekilde yerleştirildi. Hayvanlar bu işlem sırasında trendelenburg pozisyonuna getirildi. \%4'lük asetik asit çözeltisi (1 ml, pH:2,3) yavaş şekilde intrarektal kateterle rektuma uygulanarak deneysel kolit oluşturuldu. 


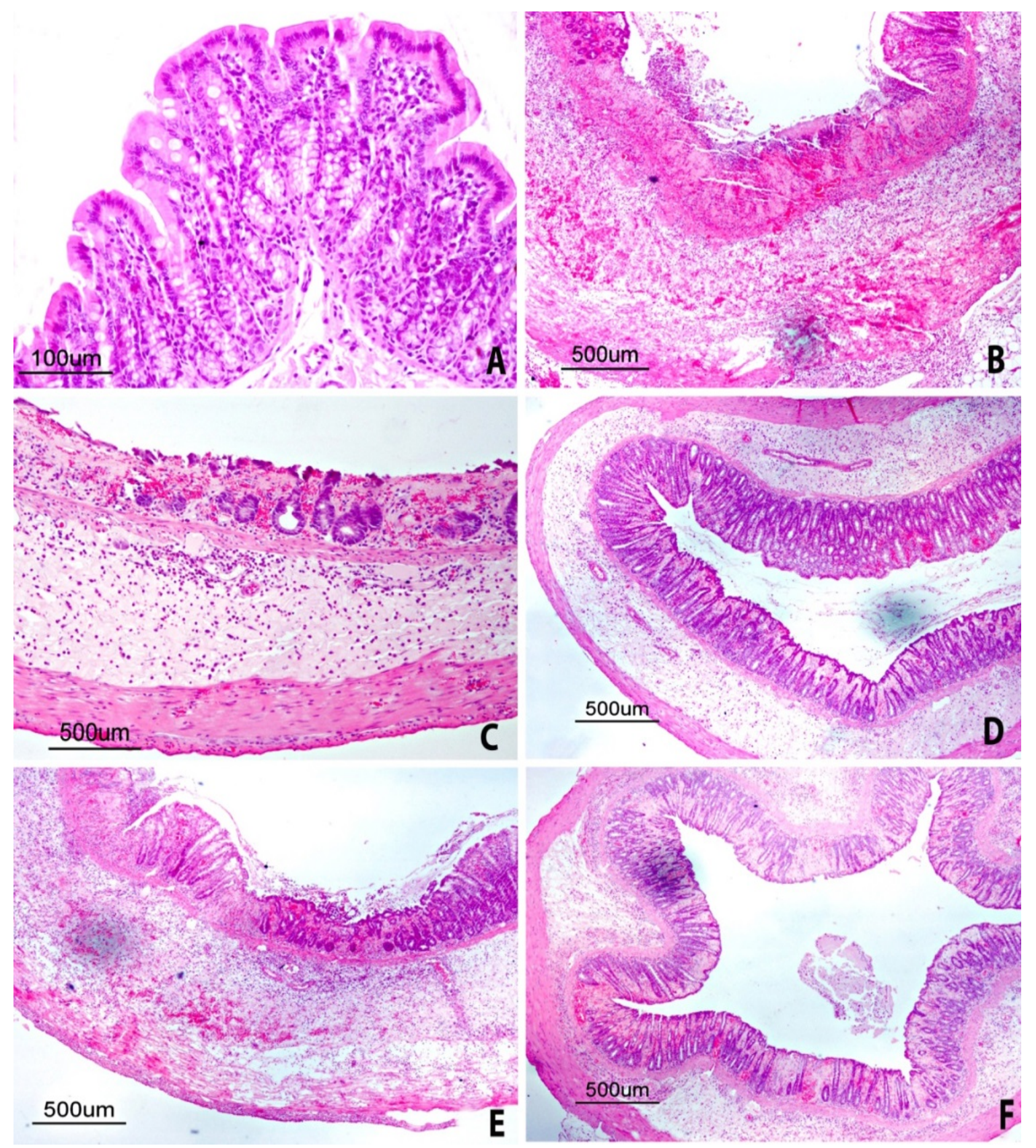

Şekil 7. A-F. Kolonun mikroskopik görünümü (H\&E). A: Kontrol grubu. Kolonun normal histolojik görünümü. B: Kolit grubu. Kolon kriptlerinde çok şiddetli erozyona bağlı yaygın kript kaybı, mukozal ve submukozal şiddetli inflamatuvar hücre infiltrasyonu ve çok şiddetli yaygın hemoraji, submukozal ödem ve vaskülitis. C: K-YKD grubu. Kolon kriptlerinde erozyon, orta derecede mukozal ve submukozal inflamatuar hücre infiltrasyonu, mukozada hafif hemoraji, yaygın submukozal ödem. D: KYKDA grubu. Genel mukozal yapı ve kript bütünlüğü korunmuş olan kolon kriptlerinde hafif derecede erozyon, mukozal ve submukozal inflamatuvar hücre infiltrasyonu, fokal mukozal hemoraji, submukozal ödem. E: K-YYD grubu. Kolon kriptlerinde orta derecede erozyon, mukozal ve submukozal inflamatuar hücre infiltrasyonu, hemoraji, yaygın submukozal ödem. F: KYYDA grubu. Genel mukozal yapı ve kript bütünlüğü korunmuş olan kolon kriptlerinde hafif derecede erozyon, mukozal ve submukozal inflamatuar hücre infiltrasyonu, fokal mukozal hemoraji, submukozal ödem.

Yüksek oranda doymuş yağ ve karbonhidrat içeren batı tipi (fast food) beslenmenin iBH gelişiminde ve prognozunda çok ciddi bir rolü olduğu uzun yıllardır tartışılmış (Ananthakrishnan ve ark., 2013; Chapman-Kiddell ve ark., 2010; Cope, 2015), bu amaçla yüksek yağlı diyet (Gruber ve ark.,
2013; Lam ve ark., 2012) ile rafine karbonhidrat, suni tatlandırıcı, şeker, pasta ve ticari tatlılar gibi aşırı miktarda alınan monosakkaritin IBH gelişimi üzerine etkisi yapılan deneysel çalışmalarda tespit edilmiştir (Jakobsen ve ark., 2013; Riordan ve ark., 1998; Sakamoto ve ark., 2005). Aralıklı diyet uygulamasının 
bazı inflamasyon markır seviyelerini azaltıcı etkisi düşünüldüğünde toplumsal bazda kolay ve uygulanabilir aralıklı diyet periyotlarının tespit edilmesi ve toplum sağlığını koruma, hayat standardını arttırma adına büyük adımlar atılmasına sebep olabilir. Patterson ve ark. (2015), insanda uzun süreli günlük aralıklı diyetler yerine gece boyunca herhangi bir diyet alınmayarak gün içerisinde belirli bir süre açlık dönemi uygulamasının da benzer etkiler sunabileceğini belirtmişlerdir. Bu sayede farmakolojik herhangi bir müdahaleye gerek kalmaksızın veya farmakolojik uygulamalara takviye olarak uygulanacak bir aralıklı diyetin hem hastalıkların oluşmasında gecikmeye hem de hastalığa yakalanmış bireylerde çeşitli etkilerle iyileştirme sürecine katkı sağlayacağı düşünülmüştür. Deneysel kolit geliştirmek için \% 4'lük asetik asit kullanılarak meydana getirilen kolit üzerine yüksek yağlı, yüksek karbonhidratlı ve aralıklı beslemenin araştırıldığı bu çalışmada aralıklı diyetin yüksek yağlı ve karbonhidratlı gruplara göre daha hafif kolit şekillendirdiği görüldü.

Deneysel çalışmalarda intrarektal asetik asit uygulanan grupların kolon dokularında makroskopik olarak lokalize hiperemi, ödem, linear ülserler ve inflamasyon bulunması makroskobik olarak inflamatuvar barsak hastalığının varlığına işaret etmektedir (Özgün ve ark., 2013). Özütemiz ve ark. (1997)'nın diltiazem, Galvez ve ark. (2001)'nın morin ile yaptıkları çalışmada kolit grubunda makroskobik olarak görülen hiperemi, linear ülserlerin kolitle birlikte diltiazem ve morin verilen gruplarda daha hafif şekillendiğini bildirmişlerdir. Öztürk (2013) yaptı̆̆ı deneysel kolit çalışmasında koruyucu olarak nesfatin-1 ve atosiban uygulamış, nesfatin-1'in kolite bağı ıelişen makroskobik hasarı azalttığını ancak atosiban uygulamasının hasarı arttırdığını vurgulamıştır. Benzer şekilde Yıldııım ve ark. (2014)'nın deneysel kolitte kolşisinin etkinliğini araştırdıkları çalışmalarında da oral ve intraperitoneal olarak verilen kolşisinin, asetik asitle oluşan kolitte makroskobik hasarı engelleyemediğini belirtmişlerdir. Yapılan bu çalışmada asetik asit ile oluşturulan kolit grubu ratların kolonlarında araştırmacıların belirttiği belirgin makroskobik hasarların meydana geldiği, yüksek karbonhidratlı ve yağı gruplarda kolit grubuna benzer bulgular görüldügü ancak aralıklı olarak verilen yüksek karbonhidratlı ve yağlı gruplarda ise bu makroskobik hasarların bariz bir şekilde azaldığı tespit edilmiştir. Bu sonuçlara göre aralıklı olarak verilen yüksek karbonhidratlı ve yağı diyetin kolite bağlı makroskobik hasarları azaltmada etkinliğinin olduğu düşünüldü.

Mikroskobik incelemelerde mukozal bariyerde bozulma, goblet hücrelerinde ve kriptlerde azalma, yaygın kriptit ve kript absesi, lamina propriada inflamatuvar hücre artışı ve mukus kaybı ÜK tanısı için önemli histopatolojik bulgular olarak tanımlanmaktadır (Cross ve Harison, 2002). Araştırmacıların farklı yöntemler uygulayarak gerçekleştirdikleri deneysel çalışmalarında da kolit oluşturulan gruplarda yukarıda bahsedilen bulgulara benzer mikroskobik bulgular görüldüğü bildirilmiştir. Obermeier ve Kojouharoff (1999) goblet hücrelerinde ve kriptlerde azalma, nötrofil, lenfosit ve makrofajların infiltrasyonu, Torres ve ark. (1999) mukoza epitelinde ülserasyon ve deskuamasyon, lamina propriada PNL infiltrasyonu, ödem, transmural inflamasyon ve çeşitli derecelerde lenfosit infiltrasyonu gözlendiği bildirilmiştir. Yine Aslan ve ark. (2008) ile Yılmaz ve ark. (2010)'nın yaptıkları çalışmada da hemoraji, şiddetli inflamatuvar hücre infiltrasyonu, submukozal ödem ve fokal ülserasyon, epitelyal hücre kaybı, kript absesi ve Goblet hücre hasarı görüldüğü belirtilmektedir. Yapılan bu çalışmada kolitli ratlarda kriptlerde çok şiddetli erozyon, mukozal ve submukozal yoğun inflamatuar hücre infiltrasyonu, yaygın submukozal ödem, hemoraji, vaskülitis, epitelyal hücre kaybı, kript absesi ve goblet hücre hasarı gibi araştırıcıların çalışmalarına benzer bulgular görülmüştür.

Beslenme tipi ve ÜK risk ilişkisinin araştıııldığı çalışmalarda yüksek yağlı veya karbonhidratlı diyetlerin bu riski belirgin olarak arttırdığı vurgulanmıştır. (Thornton ve ark., 1979; Tragnone ve ark., 1995; Reif ve ark., 1997; Sakamoto ve ark., 2005) Trans yağ ihtiva eden YYD ile yapılan birçok çalışmada indüklenen kolitin olumsuz olarak etkilendiği vurgulanmış (Ananthakrishnan ve ark., 2014; Gulhane ve ark., 2016; Montrose ve ark., 2011; Teixeira ve ark., 2011) ve bu etkinin bağırsaklarda salgı yapan goblet hücrelerinde oksidatif stres oluşturarak koruyucu mukus bariyerini oluşturan proteinlerin sentez/sekresyonunu azaltarak yangıyı tetiklediği, proteinlerin yanlış katlanmasına yol açtığı ve böylece mukozal bariyer bütünlüğünün bozulduğu varsayılmıştır (Gulhane ve ark., 2016). Benzer şekilde diyetlerinde yüksek oranda karbonhidrat içeren diyetlerin de IBH oluşumunda olumsuz bir etkisi olduğu araştırmacılar tarafından vurgulanmıştır (Hansen ve ark., 2011; Hou ve ark., 2011; Jakobsen ve ark., 2013; Maconi ve ark., 2010). Oysaki gerek aralıkı besleme gerekse günlük kalori kısıtlaması, doku ve organların fonksiyonel hücrelerinde proliferasyona neden olarak (Troyer ve ark., 1998) kardiyovasküler hastalıklar, diyabet, otoimmün hastalıklar, katarakt, osteoporozis, nörodejeneratif bozukluklar ve özellikle de bir çok kanser formları gibi önemli hastalıkların başlamasını geciktirdiği veya hastalıkların zararlı etkilerini azalttığı bildirilmiştir (Masoro, 2001; Merry 2005; Reiser ve ark 1995; Speakman ve Mitchell, 2011). Bu etkiyi antioksidan kapasiteyi arttırarak veya çok farklı seviyelerden immun sistemi harekete geçirerek gerçekleştirdiği ifade edilmiştir (Rame ve ark., 1998). Benzer şekilde kolitli deney hayvanlarında aralıklı beslenmenin inflamasyonun azalmasına neden olarak bağırsak epitel hücrelerinde rejenerasyon üzerine olumlu etki gösterdiği araştırmacılar tarafından ifade 
edilmiştir (Okada ve ark., 2017; Savendahl ve ark., 1997). Bu çalışmada yüksek karbonhidratlı ve yağlı beslenen gruplarda kolit grubundakine benzer bulgular gözlendi. Aralıklı diyet uygulanan gruplarda ise kriptler normal histolojik yapısını korumakla birlikte K-YKD ve KYYD gruplarına oranla daha hafif derecede bulgular olan kriptlerde çok hafif erozyon, mukozal ve submukozal inflamatuvar hücre infiltrasyonu, fokal mukozal hemoraji, fokal submukozal ödeme rastlanılmıştır.

$\mathrm{Bu}$ çalışmada saptanan bulgular değerlendirildiğinde makroskobik ve mikroskobik bulguların özellikle hastalığın aktivitesi ile ilişkili yapılan diğer çalışmalarla korelasyon gösterdiği ve aralıklı diyetin patolojik olarak kolit gelişiminde önleyici bir role sahip olduğu sonucuna varıldı.

\section{Kaynaklar}

Akman C, Zhao Q, Liu X, Holmes GL, 2004. Effect of food deprivation during early development on cognition and neurogenesis in therat. Epilepsy and Behavior, 5, 446454.

Ananthakrishnan AN, Khalili H, Konijeti GG, Higuchi LM, de Silva P, Korzenik JR, Fuchs CS, Willett WC, Richter JM, Chan AT, 2013: A prospective study of longterm intake of dietary fiber and risk of Crohn's disease and ulcerative colitis. Gastroenterology, 145 (5): 970-7.

Ananthakrishnan AN, Khalili H, Konijeti GG, Higuchi LM, de Silva P, Fuchs CS, Willett WC, Richter JM, Chan AT, 2014: Long-term intake of dietary fat and risk of ulcerative colitis and crohn's diseas. Gut, 63 (5), 776-784.

Appleyard CB, Wallace JL, 1995: Reactivation of hapteninduced colitis and its prevention by anti-inflammatory drugs. Am J Physiol, 269, 119-25.

Aslan A, Polat G, Atik E, Temiz M, Bağdatoğlu ÖT, Aban N, 2008: Deneysel ülseratif kolitte selenyumun etkinliği. Mersin Üniv Sağlık Bilim Derg, 1 (2), 7-11.

Chan SS, Luben $R$, van Schaik $F$, Oldenburg B, BuenodeMesquita HB, Hallmans G, Karling P, Lindgren S, Grip O, Key T, Crowe FL, Bergmann MM, Overvad K, Palli D, Masala G, Khaw KT, Racine A, Carbonnel F, BoutronRuault MC, Olsen A, Tjonneland A, Kaaks R, Tumino R, Trichopoulou A, Hart AR, 2014: Carbohydrate intake in the etiology of Crohn's disease and ulcerative colitis. Inflamm Bowel Dis, 20, 2013-2021.

Chapman-Kiddell CA, Davies PS, Gillen L, Radford-Smith GL, 2010: Role of diet in the development of inflammatory bowel disease. Inflamm Bowel Dis, 16, 137-151.

Cope G, 2015: Overview of dietary choices for ulcerative colitis and Crohn's disease. Gastrointestinal Nursing, 13,1, 33-37.

Cross SS, Harison RF, 2002: Discriminant histological feature in the diagnosis of chronic idiopathic inflammatory bowel disease: analysis of a large dataset by a novel data visualisation technique. J Clin Pathol, 55, 51-7.

Daneshmand A, Mohammadi H, Rahimian R, 2011: Chronic lithium administration ameliorates 2, 4, 6-trinitrobenzene sulfonic acid-induced colitis in rats; potential role for adenosine triphosphate sensitive potassium channels. J Gastroenterol Hepatol, 26 (7), 1174-1181.

Dieleman LA, Ridwan BU, Tennyson GS, 1994: Dextran sulfate sodium-induced colitis occurs in severe combined immunodeficient mice. Gastroenterology, 107, 1643-52.

Ewaschuk, J.B. ve Dieleman, L.A., 2006. Probiotics and prebiotics in chronic inflammatory bowel dis-eases. World J Gastroenterol, 12 (37), 5941-5950.

Galvez J, Coelho G, Crespo ME, Cruz T, Rodriguez-Cabezas ME, Concha A, 2001: Intestinal anti-inflammatory activity of morin on chronic experimental colitis in the rat. Aliment Pharmacol Ther, 15, 2027-39.

Griffiths AM, Buller HB, 2000: Inflammatory Bowel Disease In: Pediatric Gastrointestinal Disease. Eds: Walker, Durie, Hamilton, 3rd ed,: B.C. Decker Inc, Ontario, p. 613- 52.

Gruber L, Kisling S, Lichti P, Martin FP, May S, Klingenspor M, Lichtenegger M, Rychlik M, Haller D, 2013: High fat diet pathogenesis of murine Crohn's disease-like ileitis independently of obesity. PLoS One, 8(8), e71661.

Gulhane $M$, Murray L, Lourie R, Tong $H$, Sheng $Y H$, Wang R, Kang A, Schreiber V, Wong KY, Magor G, Stuart D, Begun J, Florin TH, Perkins A, Cuív PÓ, McGuckin MA, Hasnain SZ, 2016: High fat diets induce colonic epithelial cell stress and inflammation that is reversed by IL-22. Scientific Reports, 6, 28990.

Hagar H, Medany A, Eter E, 2007: Ameliorative effect of pyrrolidinedithiocarbamate on acetic acid-induced colitis in rats. Eur J Pharmacol, 554, 69-77.

Hagopian K, 2005: Krebs cycle enzymes from livers of old mice are differantially regulated by caloric restriction. Phsiol and Behavior, 85, 581-592.

Hansen TS, Jess T, Vind I, Elkjaer M, Nielsen MF, Gamborg M, Munkholm P, 2011: Environmental factors in inflammatory bowel disease: a case-control study based on a Danish inception cohort. J Crohns Colitis, 5, 577584.

Hopfer U, 1997: Digestion and Absorbtion of Basic Nutritional ConstituentsIn: Devlin Thomas M, Editor. Textbook of Biochemistry with Clinical Correlations 4th ed. New York: Von Hoffmann Press, p. 1056-1083.

Hou JK, Abraham B, El-Serag H, 2011: Dietary intake and risk of developing inflammatory bowel disease: a systematic review of the literature. Am J Gastroenterol, 106(4), 563573.

Jakobsen C, Paerregaard A, Munkholm P, Wewer V, 2013: Environmental factors and risk of developing paediatric inflammatory bowel disease -- a population based study 2007-2009. J Crohns Colitis, 7, 79-88.

Kumar V, Abbas K.A, Fausto M, 2007: Robbinson's Basic Pathology 8. Edition. 612-616.

Maconi G, Ardizzone S, Cucino C, Bezzio C, Russo AG, Bianchi Porro G, 2010: Pre-illness changes in dietary habits and diet as a risk factor for inflammatory bowel disease: a case-control study. World J Gastroenterol, 16, 42974304.

Lam YY, Ha CW, Campbell CR, Mitchell AJ, Dinudom A, Oscarsson J, Cook DI, Hunt NH, Caterson ID, Holmes AJ, Storlien LH, 2012: Increased gut permeability and microbiota change associate with mesenteric fat inflammation and metabolic dysfunction in dietinduced obese mice. PLoS One 7(3): e34233. doi:10.1371/journal.pone.0034233. 
Longo VD, Panda S, 2016: Fasting, circadian rhythms, and time-restricted feding in healthy lifespan. Cell Metab, 23, 1048-1059.

Malafaia AB, Nassif PAN, Ribas CAPM, Ariede BL, Sue KN, Cruz MA, 2013: Obesity Induction With High Fat Sucrose In Rats. ABCD Arq Bras Cir Dig, 26, 1, 17-21.

Masoro EJ, 2001: Physiology of aging. Int J Sport Nutr Exerc Metab, 218-22.

Merry BJ, 2005: Dietary restriction in rodents- delayed or retarded ageing? Mech Aging Dev,126, 951-959.

Montrose DC, Horelik NA, Madigan JP, Stoner GD, Wang LS, Bruno RS, Park HJ, Giardina C, Rosenberg DW, 2011: Anti-inflammatory effects of freeze-dried black raspberry powder in ulcerative colitis. Carcinogenesis, 32 (3), 343-350.

Morris GP, Beck PL, Herridge MS, Depew WT, Szewczuk MR, 1989: Hapten-induced model of chronic inflammation and ulceration in the rat colon. Gastroenterology, 96 (3), 795-803.

Nagib MM, Tadros MG, ELSayed MI, Khalifa AE,2013:Antiinflammatory and anti-oxidant activities of olmesartan medoxomil ameliorate experimental colitis in rats. Toxicol Appl Pharmacol, 271 (1),106-113.

Obermeier F. Kojouharoff G, 1999: Interferon-gamma (IFN- $\gamma$ )and tumour necrosis factor (TNF)-induced nitric oxide as toxic effector molecule in chronic dextran sulphate sodium (DSS)-induced colitis in mice. Clin Exp Immunol, 116, 238-245.

Okada T, Otsubo T, Hagiwara T, Inazuka F, Kobayashi E, Fukuda S, Inoue T, Higuchi K, Kawamura YI, Dohi T, 2017: Intermittent fasting prompted recovery from dextran sulfate sodium_induced colitis in mice. J Clin Biochem Nutr, 61, 2, 100-107.

Ordás I, Eckmann L, Talamini M, Baumgart DC, Sandborn WJ, 2012: Ulcerative colitis. Lancet, 380, 1606-1619.

Özgün E, Özgün GS, Eskiocak S, Yalçın Ö ve Gökmen SS, 2013: Effect of L-carnitine on serum paraoxonase, arylesterase and lactonase activities and oxidative status in experimental colitis. Turk J Biochem, 38 (2), 145-153.

Öztürk Ç, 2013: Nesfatin-1'in sıçanda asetik asit ile indüklenmiş kolitte anti-inflamatuvar etkisi ve altta yatan mekanizma. Yüksek Lisans Tezi, MU Sağlık Bilimleri Enstitüsü, İstanbul.

Özütemiz AÖ, Ünsal B, Alkanat M, Aksöz K, Dinçer Ç ve Batur Y, 1997: Sıçanlardaki asetik asit kolitinde diltiazemin etkisi. Turk J Gastroenterol, 8, 300-3004.

Patterson RE, Laughlin GA, Sears DD, LaCroix AZ, Marinac C, Gallo LC, Hartman SJ, Natarajan L, Senger CM, Martínez $\mathrm{ME}$, and Villaseñor A, 2015: Intermittent Fasting And Human Metabolic Healt. J Acad Nutr Diet, 115 (8), 12031212.

Podolsky DK, 2009: Inflammatory bowel disease. N Engl Med, 347 (6), 417-29.

Rame LT, Hart RW, Leakey JEA, 1998: Calorie restriction as a mechanism mediating resistance to environmental disease. Environ. Health Perspect, 106, 313-324.

Reif S, Klein I, Lubin F,1997: Pre-illness dietary factors in inflammatory bowel disease. Gut, 40, 754-60.
Reiser K, Mcgee C, Rucker R, Mcdonald R, 1995: Effect of aging and caloric restriction on extracellular-matrix biosynthesis in a model of injury repair in rats. $J$ of Geront Series A-Biol Sci.and Med Sci, 50, B40-B47.

Riordan AM, Ruxton CH, Hunter JO, 1998: A review of associations between Crohn's disease and consumption of sugars. Eur J Clin Nutr, 52, 229-238.

Sakamoto N, Kono S, Wakai K, 2005: Dietary risk factors for inflammatory bowel disease: a multicenter case-control study in Japan. Inflamm Bowel Dis, 11, 154-63.

Savendahl L, Underwood LE, Haldeman KM, Ulshen MH, Lund PK, 1997: Fasting prevents experimental murine colitis produced by dextran sulfate sodium and decreases interleukin-1 and insulin-like growth factor-1 messenger ribonucleic acid. Endocrinology, 138, 734-740.

Schrauwen P, Westerterp KR, 2000: The role of high-fat diets and physical activity in the regulation of body weight. $\mathrm{Br}$ J Nutr, 84 (4), 417-27.

Speakman JR, Mitchell SE, 2011: Caloric restriction. Molec Aspects of Med, 32, 159-221.

Teixeira LG, Leonel AJ, Aguilar EC, Batista NV, Alves AC, Coimbra CC, Ferreira AV, de Faria AM, Cara DC, Alvarez Leite JI, 2011:The combination of high-fat diet-induced obesity and chronic ulcerative colitis reciprocally exacerbates adipose tissue and colon inflammation. Lipids Health Dis, 10, 204.

Thornton JR, Emmett PM, Heaton KW,1979: Diet and Crohn's disease: characteristics of the pre-illness diet. Br Med J, 2, 762-4.

Torres MI, Garcia-Martin M, Fernandez MI, Nieto N, Gil A, Rios A, 1999: Experimental colitis induced by trinitrobenzenesulfonic acid: an ultrastructural and histochemical study. Dig Dis Sci, 44, 2523-9.

Tragnone A, Valpiani D, Miglio F, 1995: Dietary habits as risk factors for inflammatory bowel disease. Eur J Gastroenterol Hepatol, 7, 47-51.

Troyer DA, Venkatraman JT, Fernandes G, 1998: Effects of calorie restriction and $\omega-3$ dietary fat on aging in shortand long-lived rodents. Age, 21, 175-182.

Uygun A, Saka M, 2005: Spesifik gastrointestinal sistem hastalıklarında beslenme. Güncel Gastroenteroloji, 9 (2), 145-155.

Yıldııım B,Tuncer C, Şahin D, Dinçel AS, Göçün FPU, Leventoğlu S, Sancak S, Altan N, Dursun A, 2014: Effect of colchicine on experimental acetic acid induced colitis, Turk $J$ Biochem, 39 (1), 63-69.

Yılmaz A, Eskiocak S, Altaner Ş, Turan N, 2010: Asetik asitle Kolit Geliştirilen Sıçanlarda N-asetilsisteinin Protein Oksidasyonuna Etkisi. J Turk Clin Biochem, 8(1), 23-33.

Zhou X, J De Schepper, D De Craemer, M Delhase, G Gys, J Smitz, E L Hooghe Peters, 1998: Pituitary growth hormone release and gene expression in cafeteria-dietinduced obese rats. J Endocrinol, 159, 165-172.

*Yazışma Adresi: Ahmet UYAR,

Mustafa Kemal Üniversitesi, Veteriner Fakültesi, Patoloji Anabilim Dalı, 31040 Antakya/Hatay, Turkiye.

e-mail: uyarahmet@hotmail.com 